\title{
Menneskeavl under dyrtid og depresjon
}

\begin{abstract}
I Tidsskriftet nr. 7/1931 er det et heftig innlegg der årsakene til den økonomiske krisen drøftes med utgangspunkt i Malthus' (1766-1834) velkjente teori om menneskets formeringsevne og jordens bærekraft. Forfatteren tilbakeviser teorien med henvisning til de seneste års svake befolkningsvekst luten at han drøfter mulige årsaker, f.eks. krigen). «Overflod av mat og fabrikata bevirker så prisfall, og følgen er dårlige tider med arbeidsløshet, nød og elendighet» - altså en overproduksjonskrise. Løsningen er økte fødselstall, og her har legene et ansvar - de må ikke «drive offentlig propaganda for barnebegrensning og preventive midler». Og «skal vi også gjennem et stadium med frigivelse av abort, før den norske lægestand endelig får øinene oplatt?» appellerer han (Tidsskr Nor Lægeforen 1931; 51: 441-2).
\end{abstract}

\section{Overbefolkning eller underbefolkning? — Er Malthus' befolkningslov riktig?}

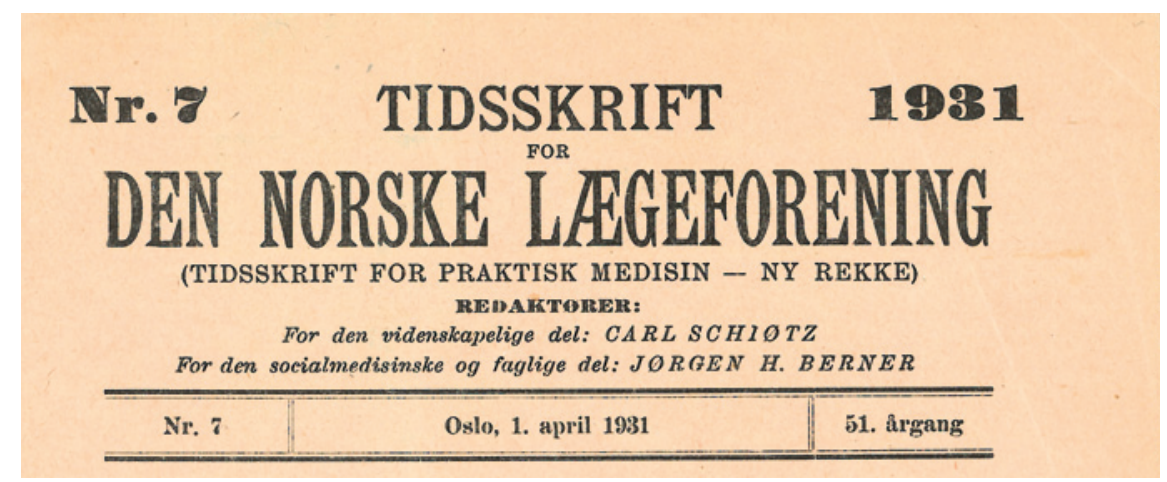

I sin bok «Menneskeavlen under kultur» skrev prof. Mohr i 1926: Menneskets antall på jorden er særlig i det siste århundre øket med svimlende fart, en fart med hvilken stigningen i tilgangen pånæringsmidler umulig kan holde følge». Og under den verdenskonjunktur som da hersket, syntes det virkelig som om Mohr kunde ha rett i det han skrev. Det var opgangstid ute i den store verden med knapphet både på råmaterialer og på næringsmidler - og derav følgende dyrtid.

Hvor ganske annerledes fortoner ikke det hele sig nu under en depresjon. I 1930 blev der produsert verden over så meget av korn på 12 måneder, at det var nok til å brødfø den nuværende verdensbefolkning i 20 - tyve - måneder. For tiden har vi med andre ord for få m ennesker til å spise alt det som mor jord i sin overdådige fruktbarhet gir oss til føde. Likeledes er der for få mennesker til å kjøpe og bruke de kolossale mengder av fabrikata som nutidens rasjonaliserte industri evner å fremstille. Overflod av mat og fabrikata bevirker så prisfall, og følgen er dårlige tider med arbeidsløshet, nød og elendighet.

For ca. 130 år siden fremsatte Malthus sin bekjente teori, som går ut på, at befolkningen har tendens til å øke efter en geometrisk rekke $(1,2,4,8,16$ o.s.v.), mens tilgangen på næringsmidler kun kan forøkes efter en aritmetrisk rekke (1, 2, 3, 4, 5 o.s.v.). Spør man så om de forløpne 130 år har bekreftet denne teori, kan svaret umulig bli annet enn : Nei. Ennu i 1930 er produksjonen av korn og levnetsmidler så stor, at der på 12 måneder kan avles en mengde som er tilstrekkelig for 20 måneders behov. Og det altså til tross for den - som Mohr gjør opmerksom på - kolossale forøkelse av verdensbefolkningen, som har funnet sted i de siste 130 år, og da særlig i siste århundre.

I sin åpningstale på generalforsamlingen januar 1931 fremholdt
G o o d e n o u g h, chef for en av de 5 store banker (Barclays bank) i England: «I tiden mellem 1913 og 1928 steg verdens folkemengde med 10 pct., mens produksjonen av fødemidler øket med 16 pct. og av råmaterialer med 40 pct.»

Skal man trekke nogen slutning av disse statistiske opgaver, må det være at mennesket i årene $1913 \mathrm{til1} 1928 \mathrm{ikke} \mathrm{har} \mathrm{evnet}$ å formeresig parallelt med dets økede evnetil å u t n y t e j ord e n - altså ganske det motsatte av Malthus' teori og Mohrs påstander.

En uhildet og upolitisk iakttager må således uvegerlig komme til det resultat, at det ikke er overbefolkning, men tvert imot underbefolkning som - i forbindelse med andre faktorer - er årsak til den nuværende verdensdepresjon. Malthus og hans tilhengere har undervurdert menneskets evne til å utnytte jorden og på den annen side overvurdert menneskets evne til å øke sitt folketall.

For de civiliserte nasjoners vedkommende er således økningen av folketallet ikke imponerende. Riktignok er den gjennemsnittlige levealder betydelig forlenget. Men på den annen side er fødselstallet falt, man kan gjerne si katastrofalt. Holder vi oss til våre hjemlige trakter, ser vi således at fødselstallet i Oslo by for tiden er ca. 9 pro mille. Det vilsi at derskal $1000-$ et tusen - menneskertil for i løpet av et år å produsere $9-n i-$ $\mathrm{n}$ y e i n d i v i d e r. Og enda finnes her læger som mener sig å gagne samfundet ved å drive offentlig propaganda for barnebegrensning og preventive midler.

Skal vi også gjennem et stadium med frigivelse av abort, før den norske lægestand endelig får øinene oplatt og reiser sig til kamp mot denne kulturnedbrytende og menneskefiendtlige avfolkningsbevegelse? - Kulturmenneskets selvmord. 